\title{
Materials for Plastic Surgery of the Dura Mater: History and Current State of the Problem (Review)
}

\author{
DOI: $10.17691 / \mathrm{stm} 2018 \cdot 10.3 .24$
}

Received January 18, 2018

D.A. Danilova, Assistant, Department of Operative Surgery and Topographic Anatomy";

L. Gorbunova, Assistant, Department of Operative Surgery and Topographic Anatomy';

S.N. Tsybusov, MD, DSc, Professor, Head of the Department of Operative Surgery and Topographic Anatomy ${ }^{1}$; 1.V. Uspensky, Chief Expert?:

L. Ya. Kravets, MD, DSc, Professor, Chief Researcher, Microneurosurgery Unit, Institute of Traumatology and Orthopedics ${ }^{1}$

1Privolzhsky Research Medical University, 10/1 Minin and Pozharsky Square, Nizhny Novgorod, 603005, Russia; I con Lab GmbH, 1 Barrikad St., Nizhny Novgorod, 603003, Russia

The review addresses one of the important aspects of modern neurosurgery: the repair of various dura mater defects. The optimal material for plastic surgery of the dura mater should meet certain biological, physical and chemical requirements, should not cause serious complications such as liquorrhea, inflammation or brain's lining scars, it should be simple and convenient in use, as well as cost-effective. The present report reviews the concepts and techniques developed in the XIX-XX centuries and also describes the materials used at the present time such as autografts (from patient's own tissues), collagen, and synthetic materials both absorbable and non-absorbable. We analyze a number of domestic and internationally-known implants used in the dura mater plastic repair. The prospects of the new synthetic Russia-made material Reperen for the dura mater plastic surgery are discussed.

Key words: defects of the dura mater; plastic repair of the dura mater; autografts; synthetic grafts; collagen transplants.

Systematic studies on plastic repairs of the dura mater (DM) began in the second half of the XIX century [1]. However, the need for new technologies able to assist in surgical treatment of brain injuries or brain tumors still remains [2].

Defects of the DM, left uncovered after the operation, can cause serious complications, such as infection of the brain and its membranes, cerebrospinal fistulas and liquorrhea, or brain's lining scars that may lead to traumatic epilepsy [3, 4].

By the end of the XIX century, many surgeons noticed that traumatic epilepsy caused by the scars formed upon a traumatic brain injury was refractory to surgical treatment [5]. Various methods of interposition of artificial materials into the wound were then proposed [6]. At first, they tried to use tiny sheets of inert metals: gold, silver, platinum. Other people were using nonmetallic grafts: gutta-percha or celluloid plates [7]. These early attempts were disappointing as the body rejected the foreign materials in various ways, e.g., by destructing the plates by the infiltrating connective tissue and by forming coarse adhesions between the brain and the overlying tissues $[8,9]$.

There were attempts to use biological materials as transplants [10]. Thus, Freeman (1908) and Saar (1911) reported the experiments on dogs and rabbits where a DM defect was closed with an egg film. The results revealed the formation of a connective tissue capsule, histologically similar to the DM tissue, which prevented the development of adhesions provided that the underlying membranes and the cortex remained intact. However, if the underlying tissue layers were damaged the risk of adhesions significantly increased [11]. In addition, this foreign material was also rejected by the body, which often resulted in an infection.

A significant contribution was made by the technique of autoplasty [12]. In this approach, a flap of patient's own tissue is transplanted into the defect area; that helped preventing the implant rejection [13-15].

The autoplastic techniques described in the literature can be divided into two large groups:

methods of non-free autoplasty of DM (using local tissues);

methods of free autoplasty.

Non-free plastic surgery manipulations were performed using a transplant with a pedicle stemming from the maternal tissue [16]. In attempts to close DM defects, a patch of periosteum was used; again, the graft included a pedicle extending from the adjacent portion of the skull, a flap of the temporal fascia along with the periosteum, a flap of the unchanged part of the DM adjacent to the defect (the Burdenko-Bruning method proposed in 1912), as well as parts of the tendon helmet. In animal experiments, a skin flap was tested

Corresponding author: Darya A. Danilova, e-mail: danilovad.a@mail.ru 
for grafting; this method is still used today in emergency neurosurgery. However, multiple complications arising in the postoperative period devaluate this approach to a great extent $[17,18]$.

There are numerous reports on partial or complete necrosis developing in the transplants, which causes inflammation and adhesions between the brain and overlying tissues. In addition, the Burdenko-Bruning method is technically complex and applicable only to small DM defects [19-21].

The method of free autoplasty involves the use of fascia for the purpose of transplantation; the wide fascia of the thigh is used most often [22, 23]. For the first time, a fascia was transplanted to close a DM defect in an experiment of Kirschner under the direction of Professor Paur in the surgical clinic of Greifswald (Germany) in 1909. In 1913, in a series of experiments on dogs and rabbits, Fedorov demonstrated that the wide fascia of the thigh was the most optimal autograft for the replacement of DM defects. In other reports, experiments with the peritoneum, tissues of the large omentum, a free flap of fatty tissue from the anterior abdominal wall, the fascia of the latissimus muscle of the back, and the anterior cog muscle were described [24-26].

However in 1978, Umakhanov showed that grafting a fascia caused gross cicatricial fusion between the brain and the overlying tissues in experimental animals; such developments may increase the risk of epilepsy. Additional disadvantages of free autoplasty were revealed in other experimental studies. For example, in free autoplasty, extra time is needed to obtain the material for transplantation, which increases the time of surgery [26]. Resorption of the transplants is often associated with a response by the surrounding tissues, which leads to the formation of adhesions and scars between the brain and the overlying structures [27, 28].

Subsequent developments in the plastic repair of DM defects were based on new discoveries in chemistry and physics, and the rapid growth of the chemical industry in the 1960s to 1980s [29]. Innovations in the techniques of preserving cadaveric biological tissues allowed scientists to harvest larger amounts of materials for potential plastic surgery and store them for a longer time. Various methods used for this purpose (treatment with formalin, lyophilization, freezing) were proposed [30]. Among them, lyophilization was most often used to conserve cadaveric DM [31].

It was found that grafts processed by lyophilization preserved not only their morphological structure but also their intact DNA and RNA, which was crucial for cell division and transplant engraftment [31, 32]. Lyophilized tissue is low-toxic, it gradually degenerates after transplantation, and eventually gets replaced by connective tissue of the recipient, which is very similar to the DM tissue.

At present, these implants are not in practical use for the following reasons [32, 33]:

a relatively strong immune response by the recipient; legal problems with the removal of cadaverous DM;

the possibility of pathogen transmission (HIV, hepatitis, syphilis, prion infections) is not ruled out;

the unusual shape and the small size of the defect make it technical difficult to provide the appropriate closure using the transplant.

Unsatisfactory results of the described methods led to the development of fundamentally new materials xenografts $[34,35]$. Those are produced from type I animal collagen and treated in such a way that the material does not cause an immunological reaction in the recipient $[36,37]$. The most commonly used transplants are prepared from bovine pericardium, bovine Achilles tendon, fetal bovine skin, porcine small intestine tissue, or from horse collagen [38, 39].

To date, there is a large assortment of collagen transplants designed for replacing DM defects, such as Durepair (Medtronic, USA), DuraGen (Integra LifeSciences Corporation, USA), DURAFORM (Codman, USA), Dura-Guard (Synovis Surgical, USA), Seprafilm (Genzyme Corporation, USA), TissuDura (Baxter, Germany), Hypro-Sorb (Bioimplon, Germany), LYOPLANT (B. Braun, Germany), Cardioplant (Cardioplant, Russia), Belkozin (Belkozin, Russia), etc. [40-44].

The material for transplant production is obtained from animals located in the territory with the geographical biohazard level BSE1 (Bovine Spongiform Encephalopathy); this is in accordance with the FDA (Food and Drug Administration, USA) guidelines and the European standards of harvesting and treating animal tissues, including the BSE inactivation procedure [45, 46]. Depending on the way of treatment, the material for transplantation can be either a strong, soft, unbreakable plate (obtained by treating the animal tissues while maintaining their structure), or porous plates of different sizes (obtained by processing animal collagen). Xenografts are capable of stimulating cell proliferation and tissue regeneration in the patient's own DM [4749]. As the new tissue is forming, the collagen plate is resorbed [50, 51]. There is a wide variety of methods for placing the grafts on DM defects: regular and seamless suturing, using gels and sealants etc. [52-57].

There are a number of advantages in using collagen grafts [58-61]. A collagen implant is simple and easy to use; easily gets adjusted to the surface of underlying tissues, which allows a surgeon to close defects of any shape; prevents the formation of DM-brain scars and the development of liquorrhea; is very similar to the natural DM by its characteristics; is replaced with the recipient's tissues within 6 months and transforms into natural DM.

Menger [51] presented a retrospective (19 years) review of prognostic factors for the development of complications after different implants were used in the course of trepanation and decompression in patients with Chiari I malformation. It showed a rise of allergic erythroderma, intermittent fever, eosinophilia and increased levels of $\operatorname{lgE}$. When the transplanted 
material was microscopically examined after its removal, abundant eosinophilic infiltration was found [62, 63] Thus, despite the appropriate processing, the material remained xenogenic. In addition, collagen transplants are costly.

In recent years, in Russia and elsewhere there is a growing interest in high-molecular inorganic materials, synthetic elastic polymers, which practically cause no acute body response and are convenient to manipulate [64-66]. Using these materials for the replacement of DM defects is not associated with an additional surgical intervention (which is often necessary when taking an autograft), the reaction of surrounding tissues to medical polymers is relatively mild and short-lived because these materials are biochemically inert and do not contribute to any antigen incompatibility $[67,68]$. Polymer products can be manufactured in any quantity, in various shapes and sizes; they do not require special conservation; they are easily sterilized and can be remodeled during the operation [69-71].

At different times, defects of the DM in experimental animals were replaced by fabrics made of lavsan, orlon, dacron, as well as with sponges made of polyvinyl formal and polyvinyl alcohol. Capron fabric was proposed as well [72]. However, these materials did not find a wide use in neurosurgery because some of them were found to accumulate calcium salts, which led to excess calcification of the implant that became hard as a bone after a short time [73, 74].

Currently, there is a great variety of absorbable and non-absorbable synthetic materials with different chemical compositions: teflon, polypropylene, silicone added polymers, etc. [75-78].

One of the most commonly used transplants is the GORE PRECLUDE membrane (WL Gore \& Associates, USA); this is a three- or two-layer membrane made of stretched polytetrafluoroethylene with a thickness of about $0.3 \mathrm{~mm}$, which is close to the thickness of natural DM. However, GORE PRECLUDE is a hydrophobic, non-biodegradable material that must be fixed with sutures (as a result, waterproofness is lost). It stays indefinitely as a foreign body inside the cranial cavity, which obviously increases the risk of adhesions and infection in the long-term postoperative period. According to different reports, the shortcomings manifest intraoperatively and sustain for 14 years after DM plastic repairs [79-82].

The Neuro-Patch membrane (B. Braun, Germany) has been well known since 1995; it is based on the European Union-approved non-resorbed DM model. It is composed from a microporous non-woven material made of highly purified polyester urethane, which allows for a rapid infiltration of the connective tissue into the transplant [82-84].

In experimental studies on rabbits, Suwanprateeb et al. [81] tested a new material made of oxidized reduced cellulose (ORC) impregnated with a solution of poly- $\varepsilon$-caprolactone (PCL). The material has good biocompatibility, promotes invasion of fibroblasts, and is convenient in application and storage. However, in other studies, allergic reactions and inflammations caused by ORC were noted. Thus, Andrychowski et al. [74] described the use of ORC (Oxycel) as a transplant in a patient undergoing surgery for a benign meningioma. In 3 months, they found (during the reoperation) that the edges of the patient's own DM were thickened by histologically confirmed intensive granulomatous, inflammation, and reaction to the foreign body.

In Russia, transplants made of relocated and surrounding tissues are used for the DM replacement, whereas small DM defects are usually repaired by suturing.

Research is now under way to produce domestic artificial materials to replace DM defects. Thus, xenografts manufactured in Russia can be exemplified by the Cardioplant endoprosthesis (Cardioplant LLC, Penza). This is a xenopericardial plate made of a nonimmunogenic material based on collagen from the bovine pericardium [43]. Upon an experimental study on pigs, Zinoviev et al. [44] recommended testing the xenopericardial plate in clinical studies on closing DM defects.

In addition, there are data on the collagenous material Belkozin (Luga plant "Belkozin"; Formed, Russia), which is the prototype of the matrix for the replacement of DM defects; earlier, the matrix was produced in Russia for limited preclinical research. Thus, in preclinical studies on rabbits, this material showed good biocompatibility with the tissues of the animal, it effectively provided liquor-stasis, and prevented the formation of brainDM scars. In this connection, Alekseev et al. [54] recommended testing the Belkozin in clinical studies.

Since 1996, the synthetic material Reperen (Icon Lab $\mathrm{GmbH}$, Russia) has been actively used in medical practice the in Russian Federation. Originally, Reperen implants found their use in ophthalmic surgery [85, 86]: for artificial lenses, glaucoma drains, artificial irises and implants for eyelid and orbital areas. Later on, the use of Reperen expanded to other sections of surgery, in particular for hernioplasty, the treatment of II-IIIA grade dermal burns, and thoracoplasty of funnel-like Grade I chest deformations. Both preclinical and clinical studies showed good acceptance of Reperen-made transplants, infrequent purulent-inflammatory complications, absence of adhesions between the implant and the recipient tissues, and much less seromas in the postoperative period [87-90].

At present, options of clinical use of Reperen polymeric implants for cranioplasty are being investigated. The results of Tikhomirova and co-workers $[91,92]$ indicate that the Reperen characteristics meet all requirements to implants used in cranioplasty. The authors also raised the possibility of using this material for repairing DM defects. They emphasized that Reperen had good biocompatibility, plasticity, the possibility of sterilization, compatibility with neuroimaging, resistance 
to a mechanical stress, low thermo and electrical conductivity, a minimal risk of infections, and an affordable price [93-102].

Therefore, all of the above allows us to define the basic requirements to the materials used in the plastic surgery of DM defects and to delineate the vector of further research. The implant should be easily remodeled and adjusted to the shape and size of the defect; it also should be biocompatible, biostable and waterproof (which prevents the development of liquorrhea and inflammatory response). The ability of undergoing sterilization and long-term storage in a sterile package as well as the optimal cost are also important when choosing the implant. The technique of closing a DM defect using this material should be simple and convenient; it should not require specialized equipment or tools so it can be used in any neurosurgical department, both in elective and emergency operations $[103,104]$.

\section{Conclusion}

Despite the close attention paid to the problem of repairing defects of the dura mater, this type of plastic surgery remains a complex and urgent task. Even the impressive selection of innovative materials and the cases of successful transplantation do not provide a universal concept of avoiding intra- and post-operative complications. This situation necessitates further research and investment into the development of novel materials, which would improve the quality of life of operated patients and help avoid complications after plastic surgery.

Research funding and conflict of interest. The study was not funded by any sources, and there are no conflicts of interest related to this study.

\section{References}

1. Shah A.M., Jung H., Skirboll S. Materials used in cranioplasty: a history and analysis. Neurosurg Focus 2014; 36(4): E19, https://doi.org/10.3171/2014.2.focus13561.

2. Balyazin V.A., Sekhveyl Salakh M.M. Osnovy neyrokhirurgii [Basics of neurosurgery]. Rostov-on-Don: Rostovkniga; 2017; 115 p.

3. Kalaev A.A., Moldavskaya A.A., Petrov V.V. The anatomic research of the dura the mater encephali and its vascular system in person with severe craniocerebral trauma not hardened by the alcoholic anamnesis and in the conditions of the alcoholic intoxication. Astrakhanskiy meditsinskiy zhurnal 2012; 7(4): 126-129.

4. Lichtermann L.B., Potapov A.A., Kravchuk A.D., Okhlopkov V.A. Clinical manifestation and surgery of craniocerebral trauma consequences. Consilium Medicum 2014; 16(9): 109-118.

5. Andresen M., Juhler M. Intracranial pressure following complete removal of a small demarcated brain tumor: a model for normal intracranial pressure in humans. $J$ Neurosurg 2014; 121(4): 797-801, https://doi.org/10.3171/2014.2.jns132209.
6. Riley E.T. Comment on arachnoid and dura mater lesions. Reg Anesth Pain Med 2018; 43(3): 332, https://doi. org/10.1097/aap.0000000000000753.

7. Vovk Yu.N., Kuvenev A.A. Age-dependent features of layer topography of convexital part of dura mater of human's brain. Eksperymental'na i klinichna medycyna 2014; 2: 49-53.

8. Konovalov A.N., Belousova O.B., Pilipenko Yu.V., Eliava Sh.Sh. Decompressive craniotomy in patients with intracranial aneurysmal hemorrhage. Voprosy neirokhirurgii im. N.N. Burdenko 2016; 80(5): 144-150, https://doi.org/10.17116/ neiro2016805144-150.

9. Sade B., Oya S., Lee J.H. Non-watertight dural reconstruction in meningioma surgery: results in 439 consecutive patients and a review of the literature. J Neurosurg 2011; 114(3): 714-718, https://doi. org/10.3171/2010.7.jns10460.

10. Xu H., Chu L., He R., Ge C., Lei T. Posterior fossa decompression with and without duraplasty for the treatment of Chiari malformation type I-a systematic review and metaanalysis. Neurosurg Rev 2017; 40(2): 213-221, https://doi. org/10.1007/s10143-016-0731-x.

11. Fraerman A.P., Perl'mutter O.A., Shakhov A.V., Shakhov V.E., Parfenov Yu.A., Orlov V.P., Savello V.E. Gnoynaya neyrokhirurgiya [Purulent neurosurgery]. Nizhny Novgorod: Povolzh'e; 2015.

12. Zanaty M., Chalouhi N., Starke R.M., Clark S.W., Bovenzi C.D., Saigh M., Schwartz E., Kunkel E.S., EfthimiadisBudike A.S., Jabbour P., Dalyai R., Rosenwasser R.H., Tjoumakaris S.I. Complications following cranioplasty: incidence and predictors in 348 cases. J Neurosurg 2015; 123(1): 182-188, https://doi.org/10.3171/2014.9.jns14405.

13. Azzam D., Romiyo P., Nguyen T., Sheppard J.P., Alkhalid Y., Lagman C., Prashant G.N., Yang I. Dural repair in cranial surgery is associated with moderate rates of complications with both autologous and nonautologous dural substitutes. World Neurosurg 2018; 113: 244-248, https://doi. org/10.1016/j.wneu.2018.01.115.

14. Kakhkharov R.A., Flegontov A.N., Mokhov N.V. Using different duraplasty variants in the treatment of patients with Chiari malformation type I. Bulletin of Russian State Medical University 2016; 4: 56-61, https://doi.org/10.24075/ brsmu.2016-04-09.

15. Sabatino G., Della Pepa G.M., Bianchi F., Capone G., Rigante L., Albanese A., Maira G., Marchese E. Autologous dural substitutes: a prospective study. Clin Neurol Neurosurg 2014; 116: 20-23, https://doi.org/10.1016/j. clineuro.2013.11.010.

16. Turchan A., Rochman T.F., Ibrahim A., Fauziah D., Wahyuhadi J., Parenrengi M.A., Fauzi A.A., Sufarnap E., Bajamal A.H., Ferdiansyah, Suroto H., Purwati, Rantam F.A., Paramadini A.W., Lumenta C.B. Duraplasty using amniotic membrane versus temporal muscle fascia: a clinical comparative study. J Clin Neurosci 2018; 50: 272-276, https:// doi.org/10.1016/j.jocn.2018.01.069.

17. Honeybul S. Management of the temporal muscle during cranioplasty: technical note. J Neurosurg Pediatr 2016; 17(6): 701-704, https://doi.org/10.3171/2015.11.peds15556.

18. Penner V.A., Kovalenko A.P. Morphological substantiation of formation and application of allografts transplantation from a human falx cerebri. Ukrai'ns'kyj zhurnal klinichnoi' ta laboratornoi' medycyny 2013; 8(3): 76-84.

19. Yazdani N., Khorsandi-Ashtiani M.T., Tashakorinia H., 
Anari M.R., Mikaniki N. Cerebrospinal fluid leakage during temporal bone surgery: selecting intra-operative dural closure with a Dumbbell-shaped muscle graft as a surgical approach Indian J Otolaryngol Head Neck Surg 2018; 70(1): 92-97, https://doi.org/10.1007/s12070-017-1165-7.

20. Parker S.L., Godil S.S., Zuckerman S.L., Mendenhall S.K., Tulipan N.B., McGirt M.J. Effect of symptomatic pseudomeningocele on improvement in pain, disability, and quality of life following suboccipital decompression for adult Chiari malformation type I. J Neurosurg 2013; 119(5): 1159-1165, https://doi.org/10.3171/2013.8.jns122106.

21. Trofimov A.O., Tishkova S.K., Kalentiev G.V., Yuriev M.Yu., Lyakina D.D., Khomutinnikova N.E. The characteristics of management of concomitant craniofacial injury complicated by cerebrospinal fluid rhinorrhea. Sovremennye tehnologii v medicine 2013; 5(3): 74-78.

22. Lam F.C., Kasper E. Augmented autologous pericranium duraplasty in 100 posterior fossa surgeries a retrospective case series. Operative Neurosurgery 2012; 71(2): 302-307, https://doi.org/10.1227/neu. 0b013e31826a8ab0.

23. Soon Sung K., Hak C. Staged reconstruction of infected dura mater using vascularized rectus abdominis muscle. J Craniofac Surg 2012; 23(6): 1741-1743, https://doi. org/10.1097/scs.0b013e31825877ee.

24. Girod A., Boissonnet H., Jouffroy T., Rodriguez J. Latissimus dorsi free flap reconstruction of anterior skull base defects. J Craniomaxillofac Surg 2012; 40(2): 177-179, https:// doi.org/10.1016/j.jcms.2011.01.023.

25. Lee J.H., Choi S.K., Kang S.Y. Reconstruction of chronic complicated scalp and dural defects using acellular human dermis and latissimus dorsi myocutaneous free flap. Arch Craniofac Surg 2015; 16(2): 80-83, https://doi. org/10.7181/acfs.2015.16.2.80.

26. Chissov V.I., Reshetov I.V., Kravtsov S.A., Matorin O.V., Polyakov A.P., Ratushnyi M.V., Filjushin M.M., Sevrjukov F.E. Komarov A.V., Vasiliev V.N. The use of combined free autoflap based on rectus abdominis in oncological patients. Onkokhirurgiya 2012; 4(1): 9-14.

27. Mirsadykov D.A., Aminov M.A., Kholbaev R.I., Abdumazhitova M.M., Rasulov Sh.O. The surgical treatment of penetrating head injury at child. Neyrokhirurgiya 2014; 1 : 97-101.

28. Fujioka M., Hayashida K., Murakamia C., Koga Y. Preserving capsule formation after removal of dura mater complex increases risk of cranial infection relapse. J Craniofac Surg 2012; 23(5): 1579-1580, https://doi.org/10.1097/ scs.0b013e3182541f2c.

29. Sulaymanov M.Zh. Application method of decompression craniotomy with duraplastic at the severe craniocerebral trauma with dislocation syndrome. Molodoy uchenyy 2016; 7: 440-443.

30. Likhterman L.B. Traumatic epidural hematomas. Spravochnik poliklinicheskogo vracha 2013; 10: 70-78.

31. Ishmametiev I.I., Ishmametiev I.L., Samartseva N.N., Starostina V.V., Perevozchikov P.A. Tissue response to the transplantation of dura mater and alloamnion in experiment. Annaly plasticheskoy, rekonstruktivnoy i esteticheskoy khirurgii 2013; 3: 17-21.

32. Alekseev E.D., Svistov D.V. Comparative analysis of dural reconstruction methods in open brain surgery for prevention of postoperative cerebrospinal fluid leakage. Kazanskij medicinskij zurnal 2014; 95(1): 45-49.
33. Tomita T., Hayashi N., Okabe M., Yoshida T., Hamada H., Endo S., Nikaido T. New dried human amniotic membrane is useful as a substitute for dural repair after skull base surgery. J Neurol Surg B Skull Base 2012; 73(5): 302307, https://doi.org/10.1055/s-0032-1321506.

34. Ryabov A.Yu., Fadeeva I.S., Deev R.V., Vezhnina N.O., Yurasova Yu.B., Fesenko N.I., Guriev V.V., Sklyanchuk E.D., Lekishvili M.V., Akatov V.S. Experimental and morphological study of the xenogenic biological membranes. Geny $i$ kletki 2014; 9(4): 103-109.

35. Neulen A., Gutenberg A., Takács I., Wéber G., Wegmann J., Schulz-Schaeffer W., Giese A. Evaluation of efficacy and biocompatibility of a novel semisynthetic collagen matrix as a dural onlay graft in a large animal model. Acta Neurochir 2011; 153(11): 2241-2250, https://doi.org/10.1007/ s00701-011-1059-5.

36. Venediktov A.A. Razrabotka biomaterialov dlya rekonstruktivnoy khirurgii na osnove ksenoperikardial'noy tkani. Avtoref. dis. ... kand. med. nauk [Development of biomaterials for reconstructive surgery based on xenopericardial tissue. PhD Thesis]. Moscow; 2014.

37. Costa B.S., Cavalcanti-Mendes Gde A., Abreu M.S., Sousa A.A. Clinical experience with a novel bovine collagen dura mater substitute. Arq Neuropsiquiatr 2011; 69(2A): 217220, https://doi.org/10.1590/s0004-282x2011000200015.

38. Griessenauer C.J., He L., Salem M., Chua M., Ogilvy C.S., Thomas A.J. Epidural bovine pericardium facilitates dissection during cranioplasty: a technical note. World Neurosurg 2015; 84(6): 2059-2063, https://doi. org/10.1016/j.wneu.2015.08.009.

39. Ryskeldiyev N.A., Zhumadildina A.Zh., Teltayev D.K., Mustafin Kh.A., Olenbay G.I., Moldabekov A.E., Tleubergenov M.A., Doskaliyev A.Zh. Dural plasty in the posterior cranial fossa. Neyrokhirurgiya $i$ nevrologiya Kazakhstana 2013; 4(33): 18-22.

40. Parlato C., di Nuzzo G., Luongo M., Parlato R.S., Accardo M., Cuccurullo L., Moraci A. Use of a collagen biomatrix (TissuDura) for dura repair: a long-term neuroradiological and neuropathological evaluation. Acta Neurochir 2011; 153(1): 142-147, https://doi.org/10.1007/s00701-010-0718-2.

41. Mumert M.L., Altay T., Couldwell W.T. Technique for decompressive craniectomy using Seprafilm as a dural substitute and anti-adhesion barrier. J Clin Neurosci 2012; 19(3): 455-457, https://doi.org/10.1016/j.jocn.2011.09.004.

42. Bowers C.A., Brimley C., Cole C., Gluf W., Schmidt R.H. AlloDerm for duraplasty in Chiari malformation: superior outcomes. Acta Neurochir 2015; 157(3): 507-511, https://doi. org/10.1007/s00701-014-2263-x.

43. Ivanov P.V., Bulkina N.V., Kapralova G.A., Zyulkina L.A., Vedyaeva A.P. Experimental acknowledgement of possibility of use of a plate of "Kardioplant" in quality resolving membranes at use of a method of the directed regeneration of a bone fabric. Fundamental'nye issledovaniya 2013; 1(3): 67-69.

44. Zinoviev P.D., Baulin A.V., Venediktov A.A., Tolstoukhov V.S. Plastics of defects of the dura mater of the endoprosthesis "Cardioplant": an experimental study. Mezhdunarodnyy zhurnal prikladnykh i fundamental'nykh issledovaniy 2015; 3(2): 198-200.

45. De Tommasi C., Bond A.E. Complicated pseudomeningocele repair after Chiari decompression: case report and review of the literature. World Neurosurg 2016; 88: 688.e1-688.e7, https://doi.org/10.1016/j.wneu.2015.11.056.

46. Pierson M., Birinyi P.V., Bhimireddy S., Coppens J.R. 
Analysis of decompressive craniectomies with subsequent cranioplasties in the presence of collagen matrix dural substitute and polytetrafluoroethylene as an adhesion preventative material. World Neurosurg 2016; 86: 153-160, https://doi.org/10.1016/j.wneu.2015.09.078.

47. De Kegel D., Vastmans J., Fehervary H., Depreitere B., Vander Sloten J., Famaey N. Biomechanical characterization of human dura mater. J Mech Behav Biomed Mater 2018; 79: 122-134, https://doi.org/10.1016/j.jmbbm.2017.12.023.

48. Kuvenev A.A. Features of structure of basal part of dura mater of human's brain. Ukrai'ns'kyj zhurnal klinichnoi' ta laboratornoi' medycyny 2013; 8(3): 59-63.

49. Alekseev D.E., Svistov D.V., Korovin A.E., Shilin V.P. The perspectives of the creation of artificial analogues of dura mater. Klinicheskaya patofiziologiya 2015; 4: 16-21.

50. Esposito F., Grimod G., Cavallo L.M., Lanterna L., Biroli F., Cappabianca P. Collagen-only biomatrix as dural substitute: what happened after a 5-year observational followup study. Clin Neurol Neurosurg 2013; 115(9): 1735-1737, https://doi.org/10.1016/j.clineuro.2013.03.013.

51. Menger R., Connor D.E. Jr., Hefner M., Caldito G., Nanda A. Pseudomeningocele formation following chiari decompression: 19-year retrospective review of predisposing and prognostic factors. Surg Neurol Int 2015; 6(1): 70, https:// doi.org/10.4103/2152-7806.156632.

52. Sekhar L.N., Mai J.C. Dural repair after craniotomy and the use of dural substitutes and dural sealants. World Neurosurg 2013; 79(3-4): 440-442, https://doi.org/10.1016/j. wneu.2011.12.062.

53. Gonzalez-Lopez P., Harput M.V., Ture H., Atalay B., Ture U. Efficacy of placing a thin layer of gelatin sponge over the subdural space during dural closure in preventing meningocerebral adhesion. World Neurosurg 2015; 83(1): 9-101, https://doi.org/10.1016/j.wneu.2014.02.032.

54. Alekseev D.E., Svistov D.V., Matsko D.E., Alekseev E.D. Plasty of dura mater defects by collagen implants using nonsuture contact direct bonding method. Vestnik hirurgii im. I.I. Grekova 2017; 176(2): 70-76.

55. Sharipov O.I., Kutin M.A., Bayuklin A.V., Imaev A.A., Abdilatipov A.A., Kurnosov A.B., Fomichev D.V., Mikhaylov N.I., Kalinin P.L. The use of platelet gel for repair of a cerebrospinal fluid fistula of the skull base (a case report and literature review). Voprosy neirokhirurgii im. N.N. Burdenko 2018; 82(1): 86-92, https://doi.org/10.17116/neiro201882186-92.

56. Ito $H_{\text {., Kimura }}$., Sameshima T., Aiyama $H_{\text {., }}$ Nishimura K., Ochiai C., Morita A. Reinforcement of pericranium as a dural substitute by fibrin sealant. Acta Neurochir (Wien) 2011; 153(11): 2251-2254, https://doi. org/10.1007/s00701-011-1077-3.

57. Shimanskiy V.N., Poshataev V.K., Odamanov D.A., Shevchenko K.V. A technique of TachoComb application in dura mater reconstruction in surgery for posterior cranial fossa tumors. Voprosy neirokhirurgii im. N.N. Burdenko 2016; 80(5): 85-89, https://doi.org/10.17116/neiro201680585-89.

58. Williams L.E., Vannemreddy P.S., Watson K.S., Slavin K.V. The need in dural graft suturing in Chiari I malformation decompression: a prospective, singleblind, randomized trial comparing sutured and sutureless duraplasty materials. Surg Neurol Int 2013; 4: 26, https://doi. org/10.4103/2152-7806.107904.

59. Sadykov A.M., Kaliev A.B., Akhmetov K.K. The experience of posttraumatic treatment of basal liquorrhea. Neyrokhirurgiya i nevrologiya Kazakhstana 2011; 1(22): 8-10.
60. Mustafayev B.S., Mustafayeva A.S. Posttraumatic liquorrhea: diagnosis and surgical treatment. Neyrokhirurgiya $i$ nevrologiya Kazakhstana 2017; 3(48): 37-40.

61. Alekseev D.E., Svistov D.V., Nevorotin A.I., Korovin A.E., Gaivoronskiy A.I. The ultrastructure of dura mater of brain and its substitutes. Vestnik Rossiyskoy voennomeditsinskoy akademii 2016; 4(56): 103-112.

62. Nagel S.J., Reddy C.G., Frizon L.A., Chardon M.K., Holland M., Machado A.G., Gillies G.T., Howard M.A., Wilson S. Spinal dura mater: biophysical characteristics relevant to medical device development. J Med Eng Technol 2018; 42(2): 128-139, https://doi.org/10.1080/03091902.2018. 1435745.

63. Pashaev B.Yu., Bochkarev D.V., Danilov V.I., Krasnozhen V.N., Vagapova G.R. Improved methods of reconstruction of defects in the skull base transnasal surgery for skull base pathology. Dnevnik kazanskoy meditsinskoy shkoly 2015; 2(8): 23-27.

64. Schmalz P., Griessenauer C., Ogilvy C.S., Thomas A.J. Use of an absorbable synthetic polymer dural substitute for repair of dural defects: a technical note. Cureus 2018; 10(1): e2127, https://doi.org/10.7759/cureus.2127.

65. Yakushin O.A., Novokshonov A.V., Agadzhanyan V.V. Use of microsurgical reconstructive techniques for treatment of patients with injuries to the spinal cord and its mater. Politravma 2015; 1: 16-22.

66. Razumovskii A.lu., Smirnova S.V. The implant substanses for the diaphragm plastics in the newborns. Khirurgiya. Zhurnal im. N.I. Pirogova 2012; 11: 90-95.

67. Khodak V.A., Petrov V.V., Dvornikov A.V., Mironov A.A., Baburin A.B., Parshikov V.V., Tsybusov S.N. The possibilities and advantages of sutureless plasty of abdominal wall using different synthetic meshes in experimental study. Sovremennye tehnologii v medicine 2012; (2): 31-36.

68. Nikolaenko V.P., Astakhov Yu.S. Treatment of orbital floor "blow-out" fractures. Part 3: Characteristics of transplant materials used. Oftalmologicheskie vedomosti 2012; 5(2): 39-56.

69. Sandoval-Sanchez J.H., Ramos-Zuniga R., de Anda S.L., Lopez-Dellamary F., Gonzalez-Castaneda R., Ramirez-Jaimes Jde L., Jorge-Espinoza G. A new bilayer chitosan scaffolding as a dural substitute: experimental evaluation. World Neurosurg 2012; 77(3-4): 577-582, https:// doi.org/10.1016/j.wneu.2011.07.007.

70. Orenstein S.B., Saberski E.R., Kreutzer D.L., Novitsky Y.W. Comparative analysis of histopathologic effects of synthetic meshes based on material, weight, and pore size in mice. J Surg Res 2012; 176(2): 423-429, https://doi. org/10.1016/j.jss.2011.09.031.

71. Kurpinski K., Patel S. Dura mater regeneration with a novel synthetic, bilayered nanofibrous dural substitute: an experimental study. Nanomedicine 2011; 6(2): 325-337, https://doi.org/10.2217/nnm.10.132.

72. Kim D.W., Eum W.S., Jang S.H., Park J., Heo D.H., Sheen S.H., Lee H.R., Kweon H., Kang S.W., Lee K.G., Cho S.Y., Jin H.J., Cho Y.J., Choi S.Y. A transparent artificial dura mater made of silk fibroin as an inhibitor of inflammation in craniotomized rats. J Neurosurg 2011; 114(2): 485-490, https://doi.org/10.3171/2010.9.jns091764.

73. Wang H., Dong H., Kang C.G., Lin C., Ye X., Zhao Y.L. Preliminary exploration of the development of a collagenous artificial dura mater for sustained antibiotic release. Chin Med $J$ (Engl) 2013; 126(17): 3329-3333. 
74. Andrychowski J., Czernicki Z., Taraszewska A., Frontczak-Baniewicz M., Przytula E., Zebala M. Granulomatous inflammation of dura mater - a rare side effect after application of hemostatic and insulation materials in case of two-stage operation of huge meningioma. Folia Neuropathol 2012; 50(4): 417-424, https://doi.org/10.5114/fn.2012.32377.

75. Terasaka S., Taoka T., Kuroda S., Mikuni N., Nishi T., Nakase H., Fujii Y., Hayashi Y., Murata J.I., Kikuta K.I., Kuroiwa T., Shimokawa S., Houkin K. Efficacy and safety of non-suture dural closure using a novel dural substitute consisting of polyglycolic acid felt and fibrin glue to prevent cerebrospinal fluid leakage - a non-controlled, open-label, multicenter clinical trial. J Mater Sci Mater Med 2017; 28(5): 69, https://doi.org/10.1007/s10856-017-5877-8.

76. Hutter G., von Felten S., Sailer M.H., Schulz M., Mariani L. Risk factors for postoperative CSF leakage after elective craniotomy and the efficacy of fleece-bound tissue sealing against dural suturing alone: a randomized controlled trial. J Neurosurg 2014; 121(3): 735-744, https://doi. org/10.3171/2014.6.jns131917.

77. Salgado C.L., Sanchez E.M., Zavaglia C.A., Granja P.L. Biocompatibility and biodegradation of polycaprolactonesebacic acid blended gels. J Biomed Mater Res A 2012; 100(1): 243-251, https://doi.org/10.1002/jbm.a.33272.

78. Rosen C.L., Steinberg G.K., DeMonte F., Delashaw J.B. Jr., Lewis S.B., Shaffrey M.E., Aziz K., Hantel J., Marciano F.F. Results of the prospective, randomized, multicenter clinical trial evaluating a biosynthesized cellulose graft for repair of dural defects. Neurosurgery 2011; 69(5): 1093-1104, https://doi.org/10. 1227/neu.0b013e3182284aca.

79. Yoshioka N. Cranial reconstruction following the removal of an infected synthetic dura mater substitute. Plast Reconstr Surg Glob Open 2014; 2(4): e134, https://doi. org/10.1097/gox.0000000000000087.

80. Matsumoto Y., Aikawa H., Tsutsumi M., Narita S., Yoshida H., Etou H., Sakamoto K., Kazekawa K. Histological examination of expanded polytetrafluoroethylene artificial dura mater at 14 years after craniotomy. Neurol Med Chir (Tokyo) 2013; 53(1): 43-46, https://doi.org/10.2176/nmc.53.43.

81. Suwanprateeb J., Luangwattanawilai T., Theeranattapong T., Suvannapruk W., Chumnanvej S., Hemstapat W. Bilayer oxidized regenerated cellulose/poly $\varepsilon$-caprolactone knitted fabric-reinforced composite for use as an artificial dural substitute. J Mater Sci Mater Med 2016; 27(7): 122, https://doi.org/10.1007/s10856-016-5736-z.

82. Deng K., Ye X., Yang Y., Liu M., Ayyad A., Zhao Y., Yuan Y., Zhao J., Xu T. Evaluation of efficacy and biocompatibility of a new absorbable synthetic substitute as a dural onlay graft in a large animal model. Neurol Res 2016; 38(9): 799-808, https:// doi.org/10.1080/01616412.2016.1214418.

83. Punchak M., Chung L.K., Lagman C., Bui T.T., Lazareff J., Rezzadeh K., Jarrahy R., Yang I. Outcomes following polyetheretherketone (PEEK) cranioplasty: systematic review and meta-analysis. J Clin Neurosci 2017; 41: 30-35, https://doi.org/10.1016/j.jocn.2017.03.028.

84. Xiong N.X., Tan D.A., Fu P., Huang Y.Z., Tong S., $\mathrm{Yu} \mathrm{H}$. Healing of deep wound infection without removal of non-absorbable dura mater (Neuro-Patch $®$ ): a case report. J Long Term Eff Med Implants 2016; 26(1): 43-48, https://doi. org/10.1615/jlongtermeffmedimplants.2016010104.

85. Khomutinnikova N.E., Orlinskaya N.Yu., Tsybusov S.N., Durnovo E.A., Mishina N.V. Clinical and morphological evaluation of reparative regeneration of the bone tissue of the orbit when using polymer implants in the experiment. Morfologicheskie vedomosti 2015; 1: 68-74.

86. Treushnikov V.M., Viktorova E.A. Principles of manufacturing biocompatible and biostable polymer implants (review). Sovremennye tehnologii v medicine 2015; 7(3): 149171, https://doi.org/10.17691/stm2015.7.3.20.

87. Khubutiia M.Sh., lartsev P.A., Rogal' M.L., Lebedev A.G., Raskatova E.V. Biological implants for hernioplasty. Khirurgiya. Zhurnal im. N.I. Pirogova 2011; 4: 9-12.

88. Pogodin I.E., Ruchin M.V., Struchkov A.A. The treatment of dermal burns with the use of hydrosurgical system "Versajet" and biopolymer "Reperen". Medicinskij al'manah 2013; 3(27): 120-121.

89. Krupko A.V., Bogos'yan A.B., Krupko M.S. Use of reperen polymer meshes in surgical treatment of pectus excavatum. Travmatologiya $i$ ortopediya Rossii 2014; 3(73): 69-75.

90. Shesterikov A.A., Lalov Yu.V., Fomin P.A., Uspenskii I.V. Hermetiszation of the turkish saddle fundus with the "Reperen-ST" synthetic implant in a combined treatment of the chiasmal and sellar area tumors. Sovremennye tehnologii $v$ medicine $2011 ; 1: 6-10$.

91. Tikhomirov S.E., Tsybusov S.N., Kravets L.Ya. Soft tissue response to grafting of polymer implant "Reperen". Neirokhirurgiya 2012; 3: 45-52.

92. Tikhomirov S.E. Plastika defektov svoda cherepa plastinami "Reperen" (eksperimentalno-klinicheskoe issledovanie). Avtoref. dis. ... kand. med. nauk [Calvarium defect plasty with "Reperen" plates (experimental and clinical study). PhD Thesis]. Nizhny Novgorod; 2011.

93. Parshikov V.V., Snopova L.B., Zhemarina N.V., Prodanets N.N., Baskina O.S., Khodak V.A., Petrov V.V., Dvornikov A.V., Mironov A.A., Tsybusov S.N. Morphological characteristics of reparative process after intraperitoneal abdominal wall mesh plasty depending on endoprosthetic material and structure in experiment. Sovremennye tehnologii $v$ medicine 2013; 5(3): 23-30.

94. Chipizubov V.A., Petrov S.I. The role of early skeletal plastics of a skull defect in the rehabilitation of patients who underwent decompressive trepanation of the skull for nontraumatic intracranial hemorrhage. Consilium Medicum 2017; 19(2): 40-43.

95. Tikhomirov S.E., Tsybusov S.N., Kravets L.Ya., Fraerman A.P., Balmasov A.A. Plasty of the base of the skull defects and dura mater with the Reperen's new polymer material. Sovremennye tehnologii v medicine 2010; 2: 6-11.

96. Sheludyakov A.Y., Tikhomirov S.E., Stupak Y.A. The use of protector made of reperen in microvascular decompression of trigeminal nerve. Sovremennye tehnologii v medicine 2014; 6(1): 121-123.

97. Verbitskiy D.A. Primenenie gelya karboksimetiltsellyulozy dlya profilaktiki spaykoobrazovaniya v bryushnoy polosti. Avtoref. dis. ... kand. med. nauk [The use of carboxymethylcellulose gel to prevent adhesion in the abdominal cavity. PhD Thesis]. Saint Petersburg; 2004.

98. Zhao D., Tao S., Zhang D., Qin M., Bao Y., Wu A. "Five-layer gasket seal" watertight closure for reconstruction of the skull base in complex bilateral traumatic intraorbital meningoencephaloceles: a case report and literature review. Brain Inj 2018; 32(6): 804-807, https://doi.org/10.1080/02699 052.2018.1440631. 
99. Kropotov M.A., Sobolevskiy V.A., Bekyashev A.Kh., Lysov A.A., Dikov Yu.Yu. Scalp and calvarial reconstruction after tumor resection. Annals of surgery 2015; 1: 21-30.

100. Shahinian G.G., Gulzatyan A.A., Makarevich D.A., Dreval O.N. Treatment of basal CSF leakage in patients with severe craniofacial damage. Rossiyskiy neyrokhirurgicheskiy zhurnal im. professora A.L. Polenova 2014; 6(4): 35-49.

101. Honeybul S., Ho K.M. Cranioplasty: morbidity and failure. Br J Neurosurg 2016; 30(5): 523-528, https://doi.org/10. 1080/02688697.2016.1187259.

102. Krylov V.V., Petrikov S.S., Talypov A.E., Puras Yu.V., Solodov A.A., Levchenko O.V., Grigoryeva E.V., Kordonskiy A.Yu. Modern principles of surgery severe craniocerebral trauma. Neotlozhnaya meditsinskaya pomoshch 2013; 4: 39-47.

103. Stupak V.V., Mishinov S.V., Sadovoy M.A., Koporushko N.A., Mamonova E.V., Panchenko A.A., Krasovsky I.B. Modern materials used to close defects of the bones of the skull. Sovremennye problemy nauki $i$ obrazovaniya 2017; 4: 38.

104. Potapov A.A., Kornienko V.N., Kravchuk A.D., Likhterman L.B., Okhlopkov V.A., Eolchiyan S.A., Gavrilov A.G., Zakharova N.E., Yakovlev S.B., Shurkhai V.A. Modern technology in the surgical treatment of head injury sequelae. Vestnik Rossiiskoi akademii meditsinskikh nauk 2012; 67(9): 31-38, https://doi.org/10.15690/vramn.v67i9.404. 